"This article is Edward Elgar Publishing and permission has been grant for this version to appear here http://www.elgaronline.com/view/9781781005309.00007.xml. The version: Oliver Morrissey, Ricardo Lopez and Kishor Sharma (Eds), 2015, Trade, tariffs, growth and poverty in:

Handbook on Trade and Development, Cheltenham: Edward Elgar, pp1937. Edward Elgar does not grant permission for this article to be further copied/distributed or hosted elsewhere without the express permission from Edward Elgar Publishing. The chapter is for private use only" [DOI:

10.4337/9781781005316]. 


\title{
Trade, Tariffs, Growth and Poverty
}

\author{
Charles Ackah, Vincent Leyaro and Oliver Morrissey
}

Pre-proof version of Chapter 2 in Oliver Morrissey, Ricardo Lopez and Kishor Sharma (Eds), Handbook on Trade and Development, Cheltenham: Edward Elgar (2015), pp19-37_(www.e-elgar.com)

\subsection{Introduction}

Increased globalisation and widespread trade liberalisation in developing countries since the 1980s has inspired considerable debate on the impact of globalisation in general, and trade liberalization in particular, on growth, incomes and poverty. This chapter provides an overview of the issues and evidence in a selective literature review. After considering why trade is important and arguments for and against protection in the remainder of this section, we focus on three issues. Section 2.2 provides an overview of the literature on the relationship between trade and growth noting that whilst a positive correlation is well established it is difficult to assert 'causality' (whether trade drives growth or growth leads to increased trade). Section 2.3 addresses the related issue of how trade liberalisation (trade policy reforms reducing barriers to trade, especially on imports) affects growth, for which the evidence is less clear. Section 2.4 considers the broader issue of how trade relates to poverty, especially in low-income countries (LICs) or sub-Saharan Africa (SSA). Section 2.5 provides a very brief conclusion.

Economists disagree about many things, but one proposition that attracts widespread agreement is that high barriers to trade damage the economy, especially if there is considerable variation across sectors and products in the extent of barriers (as this induces prices distortions that generate inefficiency). If a country imposes high tariffs or other restrictions on imports to protect domestic producers, this benefits producers of importcompeting goods (who can charge higher prices and earn economic rents) but is a disincentive to producers of exports, who are not protected and face higher prices for inputs, and imposes a cost on consumers (who pay for protection through higher prices). Note also that because access of other countries to the market is restricted, protection also harms foreign exporters. In this way protection promotes (global) economic inefficiency: resources 
are directed towards import-competing sectors where the economy may not have any comparative advantage, and away from export sectors in which it does have a comparative advantage. When countries reduce protection (liberalize trade) it encourages a more efficient allocation of resources. This is why the WTO promotes multilateral trade liberalization: if all countries liberalize together the potential benefits (from increased market access and a more efficient allocation of resources globally and within countries) are greater.

In simple terms, the benefit of trade is that it increases the size of the available market, allowing countries to specialise in production where they have a comparative (factor endowments) or competitive (technology and productivity) advantage, thus availing of scale economies and facilitating a more efficient global allocation of resources. Exports provide two basic benefits: providing access to a larger market and generating the money to purchase imports; export production also encourages specialising in products in which the country is relatively competitive. Imports also provide two basic benefits. First, access to a greater variety of (cheaper, imported) products increases consumer welfare and shifts out the consumption possibility frontier. Second, producers have access to more, cheaper, better quality inputs, especially capital goods (importing embodied technology), allowing them to become more productive. The combination of these benefits is encompassed in the view that 'openness (trade) is good for growth', where openness is measured as imports plus exports as a share of GDP. This standard trade volume measure of openness can be interpreted as a measure of the degree of trade integration with the global economy.

There are four broad ways in which trade benefits an economy; trade policy reforms are intended to increase the ability to avail of these benefits (the first three, taken together, are the static gains from trade - countries can expand production and consumption possibilities and allocate resources more efficiently).

Trade implies that the country has access to a global market that is much larger than the domestic market. For many products, production costs fall as the volume produced increases, so access to a larger market increases the amount that can be produced competitively. This is especially beneficial for small countries.

Trade encourages a more efficient allocation of resources. Countries are encouraged to concentrate on producing goods in which they are internationally competitive. These are then exchanged globally for goods the country cannot produce efficiently (exports are traded for imports). 
Imports will increase consumption possibilities by expanding the variety of goods available, usually at lower prices. A country can gain access to goods it is unable to produce itself, or at least that it is unable to produce at a lower cost than foreign producers. Note that consumers can include firms that import intermediate inputs or technology embedded in capital goods.

$\square$ Trade can contribute to economic growth, generating long-run gains. As countries engage in trade, they engage with the rest of the world. There are incentives to avail of new techniques and technologies to increase efficiency. Increases in efficiency and trade stimulate growth. There is also a macroeconomic stimulation to growth as exports earn foreign exchange that can purchase imported inputs and technology, permitting domestic demand to grow faster without generating a balance of payments deficit.

Associated with these gains, however, are costs and challenges and it is concern with these that often discourages governments from reducing barriers to trade. Exporters have to compete with producers from other countries, so there is no guarantee that access to the world market will lead to an increase in the value of exports. This is especially a problem for countries that export largely unprocessed primary commodities where the price (usually in US dollars) is determined on the world market and product differentiation is limited. A related problem is the 'fallacy of composition' where, if low-income countries simultaneously increase production of the same product (e.g. coffee, cocoa, tea) where world demand is limited, global supply increases and the price falls (typically demand is inelastic with respect to world income).

Domestic producers also face more competition in more open trade regimes. Access to an increased variety of cheap, or cheaper (than domestically produced), goods is a benefit to consumers but a challenge to local producers of import-competing goods. Some local firms will fail, imposing adjustment costs on the economy. The challenge is how local firms can respond to the competition and how the economy can adjust, i.e. can it reallocate resources effectively. The latter depends crucially on the ability of export sectors to expand; exporters face the challenge of competing on the world market. It is certainly not inevitable that the end effect is a net cost on the economy. If sufficient local firms can become competitive and the economy does reallocate resources, the country can rise to the challenge and benefit from trade. However, the poorest countries are typically the least able to respond to challenges and avail of opportunities. 
There are also potential adjustment costs of trade liberalisation on the macroeconomic side. Specifically, if imports grow faster than exports, the result is a balance of payments deficit that can have an adverse effect on growth (Thirlwall, 2003). While such an imbalance should be eliminated in the long-run, it has often been observed following trade liberalisation. This is not surprising as reforms can have a direct effect on imports, there being unconstrained supply from the rest of the world, whereas the responsiveness of exports is much slower. Thus, trade liberalising reforms are quite likely to generate a payments deficit in the short-run, imposing macroeconomic adjustment costs on the economy.

As liberalization is not costless countries may be reluctant to implement dramatic or rapid reforms, especially as governments derive benefits from protection. Three benefits are particularly important in discouraging governments from reducing trade barriers, especially tariffs.

- Trade taxes are an important source of revenue. As the formal or private wage and business sector is typically relatively small in low-income countries and it is difficult to tax the informal sector and peasant agriculture, the border is often the easiest point to levy taxes (as imports and exports are recorded at the border). This makes trade taxes attractive. Furthermore, it also means that sales taxes are more likely to be charged on imports (as they are collected at the border) than domestic goods (as internal collection is less efficient) so the appearance of reducing tariffs may not reduce the actual protection to domestic producers.

- Trade barriers can be politically advantageous to offer benefits to specific producers or sectors. The can be public support for tariffs as it can appear as if the taxes are being levied on foreign products. Influential producer groups lobby for help from the government and tariffs are a politically cheap way to assist them (and financially cheaper than subsidies).

- Trade barriers are also a way to support an industrial policy. Infant industry arguments are persuasive in many countries, even if the evidence is weak. Producer groups can argue that they need protection from imports to become competitive, and tariffs can be politically justified as supporting industrial development.

The infant industry argument is long-established and widely used to justify protectionist trade policies. The basic idea is that entrepreneurs will not invest in industries that offer a 
future potential for positive profits if current competition from foreign firms would prevent them from making a profit. If the government offers a finite period of protection from imports, the national industry could become profitable. Thus, a limited period of policy intervention will create conditions conducive to the industry's establishment.

While this is an appealing argument for industrial policy, a number of conditions must be met to provide the case for trade protection. First, the candidate industry must have a positive net present value which implies that it has the potential to become competitive and profitable, so that in time the industry and economy would benefit (and the benefits would outweigh the costs of support). This begs the question of why the entrepreneur would not be able to finance investment given expected future returns, so the second condition is market failure. It is necessary to show that there is some feature of the market that will not support the establishment of the industry (typically, the argument is missing or incomplete capital markets). The third condition is that trade policy intervention must be the 'best' option; however, tariffs are rarely optimal as they do not address the underlying market failure. The economic arguments offer little support to infant industry protection.

It is typically revenue and political economy arguments that result in the sub-optimal choice of trade protection and also help to explain why countries are slow to liberalize trade. If the empirical evidence for benefits from liberalization were compelling we could expect to see more reform. As shown in this chapter, although the evidence that exports are associated with growth is strong, the evidence that trade liberalization promotes growth or poverty reduction is quite weak.

\subsection{Trade, Openness and Growth}

The literature on 'trade and growth' is voluminous but can be classified into two opposing views. In general, the empirical evidence suggests a positive association between a measure of trade and growth, but this evidence should be interpreted carefully (Edwards, 1993). The 'optimists' view is that trade, in particular exports, is an engine of growth (Krueger, 1997). The 'sceptics' challenge the same evidence to infer, at least, that there is little support for a causal effect of trade on growth and, more specifically, that there is little evidence that trade reform itself has a significant impact on growth (Rodrik and Rodríguez, 2001). The econometric results are not highly robust and measurement and specification are very important as there are at least three conceptions of trade in the literature: 
The conventional export-led growth hypothesis focuses on export/GDP ratios as a measure of competitiveness (only efficient producers can compete on the global market) and/or 'vent for surplus' (an outlet for production above the volume required for home consumption). The evidence, in particular case studies of the high performing East Asian economies, supports the existence of a positive correlation between exports and growth, although there are competing interpretations of the implications for trade policy (Edwards, 1998).

Measures of trade openness, typically trade volume ([exports plus imports]/GDP), are interpreted as capturing integration with the world economy. This includes potential benefits of openness to imports with the benefits of exports. The underlying argument is that imports can be as important as exports and more open economies will have higher levels of imports; these increase consumer welfare and provide access to imported capital goods and intermediate inputs. Furthermore, countries with lower levels of protection (more open) will tend to have a more efficient allocation of resources and incentives, hence grow faster. The evidence suggests a strong positive correlation between openness and growth, although the causality is not so evident (Harrison, 1996). Trade advocates argue that openness is 'good for growth' hence advocate liberalization of trade policies to reduce relative price distortions, increase the return on exportables and promote economic growth. The empirical evidence linking trade liberalisation and growth is quite weak (Greenaway, Morgan and Wright, 2002). A particular problem with this literature is that it is difficult to measure with accuracy trade policy or liberalization (Milner and Morrissey, 1999) and many studies rely on dummy variables to capture the timing of liberalization episodes or use the trade volume measure of openness. Trade volume indicates the importance of international trade relative to GDP but a change in the volume may be unrelated to a country's trade policy; it is more likely, for example, to be due to a change in world market conditions for the products exported. Thus, a country may become more open in the sense that trade is a larger share of GDP without trade policy becoming more open. There need not even be a correlation between trade volume and policy openness so one should be careful to distinguish the relationship between trade volume and growth from that between trade policy and growth (discussed further in Section 2.3) 
The idea of international trade as an engine of growth goes back at least to Adam Smith and the existence of gains from trade is a long established principle in economic theory. As a consequence, many economists support the claim that trade promotes growth. According to the insights offered by traditional (neoclassical) theory of trade - trade patterns among countries are determined by comparative advantage - countries that differ in comparative advantage can benefit from trade. Increased specialization is the main channel through which trade spurs the overall growth rate. Specializing in the production of a good that each country can produce at relatively lower cost increases output and consumption in each country, hence increases welfare. The standard neoclassical theory of trade predicts effects only on levels (increases in the level of income), not on the long-run growth rate (Baldwin, 2003). More recent trade theory provides a theoretical basis for linking openness to trade with long-run growth (Krugman 1980; Grossman and Helpman 1991). This should not be interpreted as a theoretical consensus that trade leads to growth as there are many potential counter-acting effects so it is essentially an empirical question (Harrison, 1996; Baldwin, 2003).

The empirical literature identifies, on average, a positive cross-country correlation between trade and growth (e.g., Lee et al. 2004), although the relationship is not necessarily causal (Harrison, 1996; Yanikkaya, 2003). These studies are based on cross-country regressions, so results can be sensitive to the measures of trade or openness used, the sample, specification and estimator used (Edwards, 1993, 1998). In a critical review, Rodríguez and Rodrik (2001) argue that the cross-country growth regressions are fraught with so many methodological shortcomings that the findings are less robust than claimed and caution against drawing inferences that trade openness, and in particular trade liberalization, leads to economic growth. The main criticisms are the unsatisfactory measures of openness commonly used, the problem of disentangling the effects of trade policies from other factors, and the appropriate way to address various econometric concerns. The benefits from openness depend upon the presence of appropriate complementary policies and institutions - rule of law, good macroeconomic policies, adequate financial markets and functioning government institutions - implying a contingent or nonlinear relationship between openness and growth.

A simple reason for the mixed evidence is the heterogeneous nature of countries so that the conditional relationship between trade and growth may depend on country characteristics, and in particular may alter as a country develops and becomes richer (Harrison, 1996; Yanikkaya, 2003). This is plausible as poorer countries (LICs or SSA) tend to rely 
predominantly on exports of primary commodities, reflecting the undiversified structure of their economy. Primary commodity export dependence may not have a strong impact on growth because prices are determined on a world market and are volatile, so export earnings fluctuate year on year and countries are vulnerable to external shocks (Morrissey, 2005). As countries grow, manufacturing becomes more important and exports of manufactures are more likely to be associated with growth (Lederman and Maloney, 2003). Kim and Lin (2009) address this and find that there is an income threshold: below this income level (i.e., for LICs) trade is not associated with higher growth but for richer countries above the threshold trade has a positive association with growth. Herzer (2013) presents similar results: trade tends to increase income (GDP) but the magnitude of the effect varies across countries and tends to be greater in more developed (richer) countries. There does appear to be a threshold level of national income where the effect of trade on growth alters (see also Chapter 13, this volume). In the next section we will show that this threshold also seems to exist for the effect of trade policy on growth.

\subsection{Trade Policy and Growth}

The commonly used trade volume measure of openness captures the importance of international trade relative to the size of the economy but is a poor indicator of trade policy orientation. A country could have a relatively open trade policy (low barriers to imports) but a relatively low trade/GDP ratio, simply because the domestic market is very large (e.g. the US, and the EU as an entity). Similarly, a country could have relatively high import barriers (so policy is not open) and a high trade/GDP ratio because it exports a natural resource and the export earnings permit high levels of imports (e.g. Nigeria). In general small economies have higher ratios of trade to GDP than large economies irrespective of their respective policy stance. To assess the relationship between trade policy stance and growth the trade volume measure of openness is inappropriate so most studies use some measure of tariffs. Tariff measures are only an approximation of protection against imports (they exclude non-tariff barriers that can be important and averages do not capture the distortions associated with differential tariff rates) but they are the only measures that have been widely available for large number of countries over time. Milner and Morrissey (1999) provide a discussion of various methods of measuring trade policy orientation, and note that the broader measures have a limited country and time coverage. Recent studies are beginning to use measures of 
the Trade Restrictiveness Index of Anderson and Neary (2005) but so far only for a crosssection of countries in a particular year (e.g. Kee, Nicita and Olarreaga, 2009).

The most widely available simple measure of trade policy is average scheduled tariffs. While there are many difficulties in constructing this average (especially if there is high dispersion in rates), the level and changes over time is an indication of what policy-makers intend, even if an inaccurate measure of the degree, of policy reform. The nominal rate of protection $(N R P)$ is the standard simple average measure of tariffs (based on summation over all $i$ products $)$. This is defined as $N R P=(\square \mathrm{i}$ witi $) / N$ where $t i$ is the tariff rate on product $i, w i$ is the weight attached to product $i$ (usually its import share but often there is no weight) and $N$ is the total number of products with scheduled tariffs. There are numerous deficiencies in this measure, exacerbated when no weights are used. There is often a very large number of scheduled tariffs but some are redundant (i.e. apply to products which are not actually imported) and as these are often very high they can bias the mean measure. Secondary tariffs (taxes on imports that are not called tariffs) are excluded, and many imports will not attract the scheduled rate, either because the importer is entitled to exemptions or relief (widespread in most developing countries, especially LICs and SSA) or the source country is in a preferential trading arrangement, or because of evasion.

A more reliable measure at a national level is provided by the implicit nominal tariff (INT) defined as $I N T=\square \mathrm{i}(T i / M i) / N$ where $T i$ is total customs revenue on product $i, M i$ is the

total value of imports of product $i$ and $N$ as above. If available, INT would be an indicative (trade-weighted) measure of average nominal protection. However, this is only an average measure of gross protection on output, which fails to account for the effect of trade taxes on intermediate inputs. The effective rate of protection (ERP) incorporates taxes on inputs and outputs to measures the protection afforded to value added (net protection to the production process). Although ERP data have been compiled for many countries in country studies, coverage across countries over time is very limited.

To evaluate trade reform one wants to be able to capture the effects on prices, from which one can then evaluate effects on volumes and impacts on the economy. It is quite easy to measure changes in tax instruments, such as tariffs or export taxes, and these have quite direct effects on prices. While changes in other instruments can sometimes be identified easily, such as reducing quantitative restrictions or relaxing non-tariff barriers, the effects on prices can only be quantified with difficulty. Furthermore, instruments may be applied and 
altered at varying levels of intensity across different products, making it difficult to provide an aggregate summary of reforms, and even more difficult to evaluate the effect on prices and incentives. Consequently, it is extremely difficult to produce comprehensive summary measures of trade policy reform for one country, never mind for comparing countries over time (Milner and Morrissey, 1999). A common and expedient approach in the face of this difficulty is to use relatively simple measures and acknowledge their weaknesses.

Measuring the extent of trade policy openness has become one of the major challenges for studies involved in the analysis of the growth effects of trade policy (Edwards 1993, 1998; Rodrik 1998; Winters, 2004). Several studies use the trade volume measure of openness, but as noted above this is not a good policy indicator. 'In the context of policy advice, trade policy openness is most directly associated with a liberal trade regime (low tariffs, very few non-tariff barriers etc.) but in fact that is rarely the concept used in empirical work' (Winters, 2004: 4). Some studies use dummy variables to capture the timing of liberalization (e.g. Greenaway et al. 1998, 2002) or composite indices (e.g. Harrison 1996; Edwards 1998; Frankel and Romer 1999); the best known is the Sachs and Warner (1995) openness index of trade policy orientation. Kneller (2007) is a recent study adopting this approach and finds that the timing of trade liberalization has no significant effect on growth (i.e. countries that liberalize do not subsequently grow faster than similar countries that did not liberalize at the time). Inferences may depend on how quickly one expects effects to be observable. Falvey, Foster and Greenaway (2012) find that trade liberalization is associated with higher economic growth in the long run, although in the short term the costs of adjusting to liberalization may offset any growth benefits. They also find that the impact of liberalization is affected by the existence of economic crises; in particular, liberalization during an internal crisis may not benefit growth because the crisis exacerbates adjustment costs.

An alternative approach is to use a measure of average tariffs, either nominal or implicit as outlined above, as an indicator of policy and allow for the possibility of threshold effects (e.g. DeJong and Ripoll 2006; Kim and Lin 2009). These approaches are quite consistent in identifying a threshold: the poorest countries are not adversely affected by relatively high tariffs but beyond a threshold level of income higher tariffs are associated with lower growth. As this is also a finding in trade-growth literature, we illustrate with econometric analysis. All studies begin with some form of the standard growth equation 
In equation (2.1) is income (such as per capita real GDP) for country in period, reflects the average growth rate of income, is the initial income, $\boldsymbol{x}$ is a vector of determinants of economic growth, represents the unobserved country-specific factors, is a period-specific effect, is the time-varying regression residual, and $\square$ and $\square$ are parameters to be estimated.

The major econometric concern is how to address potential endogeneity. The determinants of growth in the vector $\mathbf{x}$ are unlikely to be exogenous as this requires they are uncorrelated with all past, present and future realisations of. This assumption is too restrictive and often very difficult to justify, e.g., an unanticipated shock to the growth rate of an economy could have a contemporaneous effect on exports or openness. The possibility of endogeneity together with the presence of country specific effects correlated with some of the explanatory variables implies that estimation methods such as OLS will not be consistent. One approach is to identify instruments for the trade variable. For example, Frankel and Romer (1999) use distance and geography variables to instrument for trade; Rodríguez and Rodrik (2001) argue that this may attribute effects of geography on growth to trade, overstating the effect of trade. A common approach is to employ Generalized Method of Moments (GMM) estimators (e.g. Kim and Lin 2009); although this method is subject to a problem of weak instruments, it is commonly used hence adopted for the illustration here.

To focus on the effects of the trade policy variables, (2.1) can be implemented in a parsimonious specification including only those control variables that are most frequently found to be significant in the cross-country growth literature:

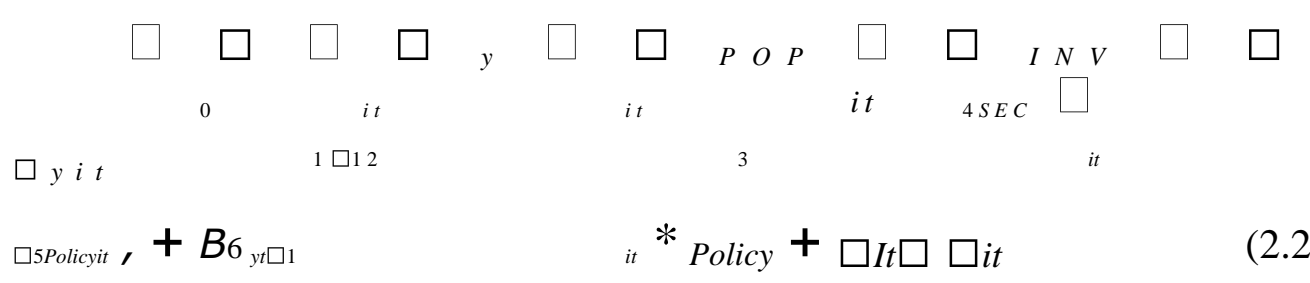

Growth $(\square y)$ is measured as the first ${ }_{12}$ difference $\left(\ln y_{i t}-\ln y_{i t-1}\right),{ }_{y i t}^{\text {where }}$ is per 
capita GDP for country $i$ in period t. Lagged income is assumed to capture unobserved country- 
specific factors, especially those that change only slowly over time (such as institutions and geography). Population growth $(P O P)$ is intended to control for size effects, whereas investment $(I N V)$ and secondary enrolment (SEC) capture physical and human capital respectively (see Appendix A2 for details on the measures). The coefficient $\square 5$ captures the average effect of trade policy on growth. The interaction term allows the growth effect of trade policy to differ for countries at different stages of development, where income is used to proxy for overall level of development (as such it also captures initial conditions).

Table 2.1 reports results of estimating (2.2) for a panel of 44 developing countries constructed by averaging data over five non-overlapping four-year time periods from 198083 through 1996-99 (limited availability of data on average tariff restricts the sample size). The countries are listed in Appendix A2 (and full details with additional results can be found in Ackah and Morrissey, 2007). The final sample consists of 19 Sub-Saharan African countries, 11 Latin American countries, 7 from East Asia, 4 from South Asia and 3 from the Middle East and North Africa (listed in Appendix Table A2.1).

Two alternative measures of trade policy (TPOLICY) are used: import tax revenue as a percentage of imports corresponding to the implicit tariff (INT) and the average (unweighted) nominal scheduled tariff $(N T R)$. The basic results are similar whichever tariff measure is used. The most robust variables affecting growth in per capita income are investment (with the expected positive effect), the growth rate of population (expected negative effect) and human capital (expected positive effect). The evidence for an effect of trade policy is weak when entered without the interaction term: negative for INT, implying that in general higher tariffs are associated with lower growth, but insignificant for NTR. As INT better captures the average aggregate rate of tax actually paid on imports it is probably more instructive than NTR.

Table 2.1 about here

The relationship observed between trade policy and growth is influenced by including the interaction term, suggesting that there is a threshold effect. Restricting attention to the preferred INT measure (results are consistent but weaker for NTR) we find positive and statistically significant effects of lagged income and of tariffs, but the interaction term is significantly negative in all cases. These results imply that the impact of trade barriers on growth is a function both of the level of restriction and of the level of income. Richer 
countries tend to have higher growth, and higher tariffs tend to be associated with higher growth, but these apply to different sets of countries (in part because richer countries have lower tariffs, and poorer countries have higher tariffs). From (2.2) the derivative of growth with respect to trade policy is calculated as $/ 35+/ 36\left(\ln y_{i t-1}\right)$.

\section{Figure 2.1 about here}

The effect of a change tariffs on growth depends on the value of the conditioning variable, the logarithm of initial GDP per capita. This is illustrated in Figure 2.1 which plots the impact of a marginal change in INT on growth against real GDP per capita for the sample. The marginal effect of protection changes from positive to negative as income increases beyond the threshold level of GDP per capita, approximately $\$ 900$ per capita (US dollars in constant international prices, base year 1985). The threshold is close to the per capita income below which countries are classed as low-income, so it appears that for LICs tariffs are not associated with lower growth and trade liberalization may not increase growth (in the medium term). In principle, trade protection retards growth and liberalization is growth-promoting once a country has reached the threshold level of GDP per capita. A corollary is that trade liberalization will not, in general, have an unambiguous effect on growth. Trade liberalisation seems to offer the possibility of achieving faster growth only in relatively richer countries.

\subsection{Trade and Poverty}

A growing literature addresses the relationship between trade and poverty reduction. One broad line of argument is that as trade supports growth and growth supports poverty reduction, trade supports poverty reduction (Dollar and Kraay, 2004). Although growth is not necessarily pro-poor, there is some evidence that trade creates a conducive environment for economic growth that benefits the poor (Bhagwati and Srinivasan, 2002; Bhagwati, 2004). However, the links are more tenuous than those from trade to growth, especially in a cross-country context, because the effect depends on the engagement of the poor and vulnerable (those close to the poverty line who may fall below) with the sector composition of trade and growth as producers, employees and consumers. 
Trade can potentially affect the poor the poor through three major channels (Winters et al., 2004): change in relative prices faced by households as consumers and producers; the market for labour (i.e. employment and wage adjustments); and public spending (as influenced by taxation and government revenue). Studies that allow for some or all of these channels are usually based on micro data such as for firms, workers or households (e.g. Goldberg and Pavcnik, 2007). Country studies use household or firm level data to either measure the impact of trade policy on employment and labour income or on poverty through changes in the prices of good consumed and/or produced by the poor (e.g. Nissanke and Thorbeke, 2007). These studies are very informative but difficult to generalize to the aggregate level across countries.

Cross-country studies using aggregate data rely on the assumption that trade and poverty are linked through economic growth: 'in the long run economic growth is the key to the alleviation of absolute poverty. It creates the resources to raise incomes, and government will have scope for stronger redistributive measures when income is higher and growth is faster' (Winters et al. 2004, p. 3). The effect of growth on poverty will depend also on inequality: Chen and Ravallion $(2004 ; 2010)$ note that although growth can be pro-poor if poverty decreases only slightly although income distribution worsens, growth is most effective at reducing poverty if it also decreases inequality. As effects of trade on poverty depend on structural characteristics of the economy and features of inequality it should be no surprise that it is difficult to find general patterns across countries.

Acknowledging the problems using aggregate national data to interpret the crosscountry correlations between growth and poverty reduction (Deaton, 2003), a number of studies follow the cross-country growth regression tradition to try and identify the broad pattern (e.g. Dollar and Kraay, 2004). A broad conclusion is that there is no evidence in the aggregate data that trade reform is bad for the poor, but a lack of robust evidence that trade is associated with poverty reduction (Winters et al. 2004; Harrison, 2006). The mixed evidence can be explained by the complexity of linkages to investigate, the limited availability of data identifying relatively direct links between trade and poverty, and the tendency of there to be winners and losers from trade so some are raised out of poverty but some non-poor become poor (Winters, 2002; Goldberg and Pavcnik, 2007). 
Consider a specification similar to (2.2) where poverty rather than growth is the dependent variable:

The dependent variable ${ }_{H i t}$ is headcount poverty measured as the percentage of the population living in households with consumption or income per person below the poverty line. The explanatory variables including the two trade measures, exports $(X)$ and trade volume (Trade), are all in logs (see Appendix A2 for definitions). Initial income (YO) captures conditional convergence or initial conditions). The expected sign is negative implying that as countries grow, the poor or developing countries will catch up with rich or developed countries. Secondary school enrolment $(S E C)$ is a proxy for human capital, and inflation $(I N F)$ represents policy distortion as a proxy for the growth retarding features of the economy. Growth rate of real GDP per capita $(g)$ is a critical variable that mediates the effects of trade on poverty. The sub-Saharan African dummy (SSA) is included as in the cross-country growth and poverty literature SSA is found to be different from other regions of the world; the SSA dummy is typically adversely associated with growth and poverty (see Chapter 13, this volume).

Table 2.2 presents illustrative results for the association between growth and poverty including trade variables based on a panel data set of 90 developing countries (a list of countries is in Appendix A2) for six 5-year non-overlapping periods between 1975 and 2005 . The Blundell and Bond (1998) system GMM estimator is used as it helps to address problems of omitted variables, endogeneity and choice of instruments. As GMM does have the problem of weak instruments, Random Effects (RE) estimates are also reported for comparison; RE is selected over Fixed Effects because $Y O$ and SSA dummy are effectively fixed. The estimates should be treated as no more than illustrative of general issues.

Table 2.2 about here 
The lagged dependent variable ${ }_{(H t-1)}$, which captures the dynamics, is positive and strongly significant, suggesting persistence of poverty within a country over time with a tendency for poverty to decline. Higher initial income (at the beginning of each sub-period) and secondary education are associated with lower poverty; given other variables, richer countries have lower poverty as expected. Growth $(g)$ has quite a strong association with lower poverty. Given these variables, more distorted economies (higher inflation) and SSA countries have higher poverty. Neither of the trade variables (exports or trade volume) have a significant effect.

There are a number of reasons why trade variables would be insignificant in this simple cross-country regression. A general concern is that most if not all of the explanatory variables are likely to be related to each other, e.g. richer countries tend to have higher education and growth and lower inflation, whereas SSA countries tend to have lower incomes, growth and education and higher levels of inflation. In this context, cross-country variations in trade variables are unlikely to have a consistent relationship with poverty. As found for trade policy and growth, threshold effects are likely to exist here also (in addition to considerable heterogeneity across countries in how trade affects the poor). Winters et al. (2004) and Nissanke and Thorbeke (2007) show that any effects of trade on poverty are likely to be varied and non-linear.

It is quite plausible that trade policy benefits the poor in low-income countries because barriers to imports shield them from competition and protect incomes. Nicita, Olarreaga and Porto (2014) show why this may be the case. They measure whether trade protection is propoor or anti-poor based on how the trade policy structure (especially tariffs) affects the incomes of the poorest $10 \%$ and richest $10 \%$ of households by estimating effects through the goods households produce (including wage effects) and the goods they consume. For six SSA countries (Burkina Faso, Cameroon, Côte d'Ivoire, Gambia, and Madagascar) they find trade policy is pro-poor, whereas in Ethiopia it is anti-poor. The reason is because protection increases the prices of agricultural products the poorest produce by more than the prices of products rich households produce, and by more than the prices of goods they consume. In this situation trade policy in SSA will tend to be pro-poor so trade liberalization may actually make the poor worse off, at least relative to the rich (so inequality is again relevant). 


\subsection{Conclusion}

A broad conclusion is that trade has the potential to promote growth but countries must be able or enabled to avail of this potential, and richer countries are better able to benefit from trade than poorer countries. The evidence for a positive relationship between trade and growth tends to be strongest for exports: countries that expand exports and sustain export growth are more likely to sustain economic growth. Insofar as growing economies are also more likely to increase exports the relationship may not be causal, although it is not unreasonable to accept that growth in export/GDP ratios will lead to increased economic growth or that a decline in export earnings will have an adverse impact on growth. The structure of exports may be important as countries (mostly low-income) dependent on primary commodity exports tend to be more vulnerable to external shocks, e.g. a collapse in the world price that reduces export earnings, than exporters of manufactures. Consequently, the relationship between trade and growth tends to become positive as a country becomes richer with a more diversified production and export structure.

For developing countries, especially LICs and SSA, using the trade volume measure of trade openness adds little to analysis based on export/GDP ratios. This is because exports tend to be volatile (primary commodities affected by conditions in the world market) whereas imports are more stable (at least in part because aid finances trade deficits). Consequently, movements in the openness measure are largely determined by changes in exports. Furthermore, whilst imported technology may enhance productivity and therefore growth, the effect would take longer to be observed than any impact of exports on growth. Thus, for general cross-country results, the relationship between trade volume and growth is largely the relationship between exports and growth.

The relationship between trade policy and growth varies across different types of countries and so will the effect of trade liberalization, at least in the relatively short term. Trade liberalization may have only a limited impact on growth in the poorest countries because of the influence of economic structure and the fact that domestic trade policy has a more immediate effect on imports than on exports. For most developing countries, exports are largely determined by policies in other countries and features of the global market; in particular, prices and demand are determined in the world market and restrictive policies in other countries constrain opportunities for developing countries to expand exports of the agriculture products in which they often have a potential comparative advantage. 
The potential benefits from trade liberalisation are not automatic and poorer countries may actually be made worse off by it. There are a number of reasons why protection may support growth, or alternatively why liberalization may adversely affect growth, in the poorest countries, noting that the results should be interpreted as relating to the relatively short run. First, import-competing sectors in these countries may be relatively underdeveloped so that even if they have the potential to be competitive and efficient, they are not so at present. This has resonance with the East Asian strategy of protecting some domestic sectors at the same time as promoting export sectors. Poor countries, such as in SSA, may not be implementing such a strategy coherently and effectively, but there may be a case (and there will be a lobby) for sheltering nascent domestic industries from import competition. Second, and related, given the underdeveloped nature of the economy and the inflexibility of markets, especially limited factor mobility, the adjustment costs to trade liberalisation can be high. Third, and more generally, weak institutions and unfavourable structural characteristics (e.g. export dependence on a narrow range of primary commodities) may mean that poor countries are unable to avail of the potential benefits from liberalization. These structural impediments limit the impact of trade and liberalization on growth, and also on poverty reduction. As many factors influence poverty and trade has no clear direct effect, it is difficult to establish any general relationship between trade, trade policy and poverty across countries. 


\section{APPENDIX A2}

\section{List of Countries for Table 2.1}

Argentina, Bangladesh, Botswana, Burkina Faso, Burundi, Cameroon, Chile, China, Congo DR, Congo Republic, Costa Rica, Côte d'Ivoire, Dominican Republic, Ecuador, Egypt, Ethiopia, Ghana, India, Indonesia, Jamaica, Kenya, South Korea, Madagascar, Malawi, Malaysia, Mauritius, Mexico, Morocco, Nepal, Nicaragua, Paraguay, Philippines, Rwanda, Sierra Leone, Singapore, South Africa, Sri Lanka, Thailand, Tunisia, Uganda, Uruguay, Venezuela, Zambia, Zimbabwe.

\section{Definitions and Sources of Data for Table 2.1}

Income $(I F)$ measured as per capita GDP, population growth rate $(P O P)$, gross domestic investment $(I N V)$ and gross secondary school enrolment $(S E C)$ are from World Development Indicators (2003) and the data series available as the Global Development Network Growth Database at www.worldbank.org/research/growth. Two trade policy measures are used (see Ackah and Morrissey, 2007): import duties as percentage of total imports (INT) is from World Development Indicators (1999) and average scheduled tariff $(N T R)$ is from http://publications.worldbank.org/catalog/content-download?revision id=1526199.

\section{List of Countries for Table 2.2}

Albania, Algeria, Angola, Argentina, Bangladesh, Benin, Bhutan, Bolivia, Botswana, Brazil, Bulgaria, Burkina Faso, Burundi, Cambodia, Cameroon, Cape Verde, Central African Republic, Chad, Chile, China, Colombia, Congo DR, Congo Republic, Costa Rica, Côte d'Ivoire, Czech Republic, Djibouti, Dominican Republic, Ecuador, Egypt, El Salvador, Ethiopia, Gabon, Gambia, Ghana, Guatemala, Guinea, Guinea-Bissau, Guyana, Haiti, Honduras, Hungary, India, Indonesia, Iran, Jamaica, Jordan, Kenya, Lesotho, Liberia, Madagascar, Malawi, Malaysia, Mali, Mauritania, Mexico, Mongolia, Morocco, Mozambique, Namibia, Nepal, Nicaragua, Niger, Nigeria, Pakistan, Panama, Papua New Guinea, Paraguay, Peru, Philippines, Poland, Kenya, Lesotho, Liberia, Madagascar, Malawi, Malaysia, Mali, Mauritania, Mexico, Mongolia, Morocco, Mozambique, Namibia, Nepal, 
Nicaragua, Niger, Nigeria, Pakistan, Panama, Papua New Guinea, Paraguay, Peru, Philippines, Poland, Romania, Russian Federation, Rwanda, Senegal, Sierra Leone, Slovenia, South Africa, Sri Lanka, St. Lucia, Suriname, Swaziland, Tanzania, Thailand, Togo, Trinidad and Tobago, Tunisia, Turkey, Uganda, Uruguay, Venezuela, Vietnam, Yemen, Zambia, Zimbabwe

\section{Definition and Sources of Data for Table 2.2}

Headcount poverty $(H)$, measured as $\%$ of population living in households with consumption or income per person below the poverty line as per World Bank 2005 is from http://iresearch.worldbank.org/PovcalNet. Growth rate of real GDP $(g)$ from Penn World Tables 2010; initial income (YO) measured as log of real GDP per capita at the beginning of each period from World Development Indicators (WDI) 2011; Inflation, consumer prices annual \% change (INF) from WDI 2011; gross secondary school enrolment in \% (SEC) is from WDI 2009; Trade (export + imports, \% of GDP) and exports of goods and services \% of GDP $(X)$ are from WDI 2011. 


\section{References}

Ackah, C., and O. Morrissey (2007), 'Trade Liberalisation is Good for You if You are Rich', School of Economics, University of Nottingham: CREDIT Research Paper 07/01 (www.nottingham.ac.uk/economics/credit/)

Anderson, J. E. and J. P. Neary (2005), Measuring the Restrictiveness of International Trade Policy, Cambridge, MA: MIT Press

Arellano, M. and S. R. Bond (1991), 'Some Tests of Specification for Panel Data: Monte Carlo Evidence and an Application to Employment Equations', Review of Economic Studies, 58 (2), 277-97.

Baldwin, R.E. (2003), 'Openness and Growth: What's the Empirical Relationship', Cambridge, MA: NBER Working Paper No. 9578.

Bhagwati, J. (2004), In Defence of Globalisation, Oxford University Press, New York

Bhagwati, J. and T.N. Srinivasan (2002), 'Trade and Poverty in the Poor Countries', AEA Papers and Proceedings, 92(2), 180-183.

Blundell, R. and S. Bond (1998), 'Initial Conditions and Moment Restrictions in Dynamic Panel Data Models', Journal of Econometrics, 87 (1), 115-143

Chen, S. and M. Ravallion (2004), 'How Have the World's Poorest Fared Since the Early 1980s?', World Bank Research Observer, 19(2), 141-70.

Chen, S. and M. Ravallion (2010). The Developing World Is Poorer Than We Thought, But No Less Successful in the Fight Against Poverty. The Quarterly Journal of Economics, $125,1577-1625$

Deaton, A. (2003), 'Measuring Poverty in a Growing World (or Measuring Growth in a Poor World)', NBER Working Paper 9822

DeJong, D. N., \& Ripoll, M. (2006), Tariffs and growth: An empirical exploration of contingent relationships, Review of Economics and Statistics, 88(4), 625-640

Dollar, D. and A. Kraay (2004), 'Trade, Growth and Poverty', The Economic Journal, 114 (493): 22-49

Edwards, S. (1993), 'Openness, Trade Liberalization, and Growth in Developing Countries', Journal of Economic Literature, 31 (3), 1358-93.

Edwards, S. (1998), 'Openness, productivity and growth: What do we really know?', Economic Journal, 108, 383-398.

Falvey, R., N. Foster and D. Greenaway (2012), Trade Liberalization, Economic Crises, and Growth, World Development, 40 (11), pp. 2177-2193

Frankel, J. and Romer, D. (1999), "Does Trade Cause Growth?", American Economic Review, vol. 89, no. 3, pp. 379-399.

Goldberg, P. K. and N. Pavenik (2007), 'Distributional Effects of Globalization in Developing Countries,' Journal of Economic Literature, 45(1): 39-82.

Greenaway, D., Morgan, W. and Wright, P. (1998), "Trade Reform, Adjustment and Growth: What does the Evidence Tell Us?", Economic Journal, vol. 108, pp. 15471561 .

Greenaway, D. Morgan, W. and Wright, P. (2002), "Trade Liberalisation and Growth in Developing Countries”, Journal of Development Economics, 67 (2), 229-244. 
Grossman, G. M. and E. Helpman (1991), Innovation and Growth in the Global Economy, Cambridge, MA: MIT Press

Harrison, A. (1996), 'Openness and Growth: A time-series, cross-country analysis for developing countries', Journal of Development Economics, 48 (2), 419-447

Harrison, A. (2006), 'Globalisation and Poverty', NBER Working Paper no. 12347, Cambridge, MA

Herzer, D. (2013), Cross-Country Heterogeneity and the Trade-Income Relationship, World Development, 44, pp. 194-211

Kee, H. L., A. Nicita and M. Olarreaga (2009). Estimating Trade Restrictiveness Indices, Economic Journal, 119(534), 172-199.

Kim, D-H. and S-C. Lin (2009), Trade and Growth at Different Stages of Economic Development, Journal of Development Studies, 45 (8), 1211-1224.

Kneller, R. (2007) 'No miracles here: trade policy, fiscal policy and economic growth' Journal of Development Studies 43 (7), 1248-1269.

Krueger, A. O. (1997), 'Trade Policy and Economic Development: How we Learn', American Economic Review, 87, 1-22.

Krugman, R.P. (1980), 'Scale Economies, Product Differentiation and the pattern of Trade', American Economic Review, 70, 950 - 959

Lederman, D. and W. Maloney (2003), 'Trade Structure and Growth', World Bank Policy Research Working Paper 3025 (www.worldbank.org).

Lee, H., Ricci L. and Rigobon, R. (2004) Once again is openness good for growth ?, Journal of Development economics, 75(2), 451-472.

Milner, C. and Morrissey, O. (1999), "Measuring Trade Liberalisation", chapter 3 in M. McGillivray and O. Morrissey (eds), Evaluating Economic Liberalisation, London: Macmillan.

Morrissey, O. (2005), 'Imports and Implementation: Neglected Aspects of Trade in the Report of the Commission for Africa', Journal of Development Studies, 41 (4), 1133 1153.

Nicita, A., M. Olarreaga and G. Porto (2014), Pro-Poor Trade Policy in Sub-Saharan Africa, Journal of International Economics (forthcoming) doi:10.1016/j.jinteco.2014.01.001

Nissanke, M., and E. Thorbecke (2007), The Impact of Globalization on the World's Poor: Transmission Mechanisms, Basingstoke: Palgrave Macmillan for UNU-WIDER

Rodríguez, F. and D. Rodrik (2001), Trade policy and economic growth: a skeptics guide to the cross-national evidence, in B. Bernanke and K. Rogoff (Eds.), NBER Macroeconomics Annual 2000, Vol. 15. Cambridge, MA: MIT Press, pp. 261-325.

Rodrik, D. (1998), "Trade Policy and Economic Performance in Sub-Saharan Africa", Cambridge, MA: NBER Working Paper No. 6562.

Rodrik, D. and Rodríguez, F. (2001), 'Trade Policy and Economic Growth: A Sceptic's Guide to the Cross-National evidence', Cambridge, MA: NBER Working Paper No.7081 
Sachs, J.D. and Warner, A.M. (1995), "Economic Reform and the Process of Global Integration," Brookings Papers on Economic Activity, vol. 1, pp. 1-118.

Thirlwall, A. P. (2003), Trade, the Balance of Payments and Exchange Rate Policy in Developing Countries, Cheltenham: Edward Elgar.

Winters, L. A. (2002), 'Trade, Trade Policy and Poverty: What are the Links', The World Economy, 25(9): 1339-1367.

Winters, L. A. (2004), 'Trade Liberalisation and Economic Performance: An Overview, Economic Journal, 114 (493): F4-F21.

Winters, A. L., N. McCulloch and A. McKay (2004), 'Trade Liberalization and Poverty: the Evidence So Far', Journal of Economic Literature, XLII (March), 72-115.

Yanikkaya, H. (2003), 'Trade openness and economic growth: A cross-country empirical investigation', Journal of Development Economics, 72( ), 57-89. 
Table 2.1 Trade Policy and Growth in Developing Countries (1980-1999)

\begin{tabular}{|c|c|c|c|c|}
\hline & \multicolumn{2}{|c|}{$I N T$} & \multicolumn{2}{|c|}{ NTR } \\
\hline $\ln Y_{t-1}$ & $\begin{array}{c}-0.003 * * \\
(0.001)\end{array}$ & $\begin{array}{l}0.022 * * * \\
(0.004)\end{array}$ & $\begin{array}{c}-0.029 * * * \\
(0.007)\end{array}$ & $\begin{array}{c}0.01 \\
(0.01)\end{array}$ \\
\hline$P O P$ & $\begin{array}{c}-0.044 * * * \\
(0.007)\end{array}$ & $\begin{array}{l}-0.03 * * * \\
(0.005)\end{array}$ & $\begin{array}{c}-0.047 * * * \\
(0.007)\end{array}$ & $\begin{array}{c}-0.037 * * * \\
(0.011)\end{array}$ \\
\hline$I N V$ & $\begin{array}{c}0.010^{* * * *} \\
(0.001)\end{array}$ & $\begin{array}{l}0.01 * * * \\
(0.001)\end{array}$ & $\begin{array}{l}0.009 * * * \\
(0.0004)\end{array}$ & $\begin{array}{c}0.009 * * * * \\
(0.0005)\end{array}$ \\
\hline$S E C$ & $\begin{array}{r}0.001 * * * \\
(0.0002)\end{array}$ & $\begin{array}{c}0.001 * * * \\
(0.0002)\end{array}$ & $\begin{array}{l}0.002 * * * \\
(0.0005)\end{array}$ & $\begin{array}{c}0.002 * * * \\
(0.0005)\end{array}$ \\
\hline Policy & $\begin{array}{c}-0.001 * * \\
(0.0004)\end{array}$ & $\begin{array}{l}0.018 * * * \\
(0.002)\end{array}$ & $\begin{array}{l}-0.0000 \\
(0.0003)\end{array}$ & $\begin{array}{c}0.013^{* * *} * \\
(0.002)\end{array}$ \\
\hline Policy* $\ln Y_{t-1}$ & & $\begin{array}{c}-0.003 * * * \\
(0.0004)\end{array}$ & & $\begin{array}{c}-0.002 * * * \\
(0.0003)\end{array}$ \\
\hline Constant & $\begin{array}{c}-0.053 * * \\
(0.021)\end{array}$ & $\begin{array}{c}-0.310^{* * * *} \\
(0.039)\end{array}$ & $\begin{array}{l}0.090^{*} \\
(0.046)\end{array}$ & $\begin{array}{c}-0.21 * * \\
(0.077)\end{array}$ \\
\hline $\begin{array}{l}\text { Period Dummies: } \\
1984-87\end{array}$ & & & $\begin{array}{c}-0.015 * * * \\
(0.005)\end{array}$ & \\
\hline 1988-91 & $\begin{array}{l}0.012 * \\
(0.007)\end{array}$ & $\begin{array}{l}0.016 * * * \\
(0.006)\end{array}$ & $\begin{array}{l}0.009 * * * \\
(0.003)\end{array}$ & $\begin{array}{l}0.014^{*} \\
(0.007)\end{array}$ \\
\hline $1992-95$ & $\begin{array}{c}-0.026 * * * \\
(0.002)\end{array}$ & $\begin{array}{c}-0.0151 * * \\
(0.006)\end{array}$ & $\begin{array}{c}-0.032 * * * \\
(0.005)\end{array}$ & $\begin{array}{c}-0.019 * * * \\
(0.005)\end{array}$ \\
\hline 1996-99 & $\begin{array}{l}0.012 * \\
(0.006)\end{array}$ & & & \\
\hline Sargan Test & [0.722] & [0.769] & [0.475] & [0.901] \\
\hline$A R(1)$ & [0.068] & [0.085] & [0.084] & [0.090] \\
\hline$A R(2)$ & {$[0.581]$} & {$[0.751]$} & [0.538] & {$[0.653]$} \\
\hline Observations & 132 & 132 & 136 & 136 \\
\hline
\end{tabular}

Notes: Results using the System GMM estimator. For the trade Policy variable, INT is implicit tariff and NTR is the average nominal tariff. Standard errors in parentheses: *, ** and *** denote significant at $10 \%, 5 \%$ and $1 \%$ level respectively. Only significant time dummies are reported. For the test statistics the $p$-values are in brackets. The Sargan test is for the validity of the set of instruments. The $A R(1)$ and $A R(2)$ are tests for first and second order serial correlation of the residual in the differenced equation. For the instruments to be acceptable, the $p$-values for the Sargan and $A R(2)$ test should both be greater than 0.05 , and the $p$-values for the $A R(1)$ should be less than 0.05 , i.e., there is first-order serial correlation but no second-order serial correlation (Arrelano and Bond, 1991). The instruments appear to be acceptable, albeit weak on $A R(1)$.

Source: Ackah and Morrissey (2007). 
Table 2.2 Determinants of Cross-Country Poverty $(H)$, 1975-2005

\begin{tabular}{|c|c|c|c|c|}
\hline & $\begin{array}{l}\mathrm{RE} \\
(1) \\
\end{array}$ & $\begin{array}{l}\text { SGMM } \\
(2)\end{array}$ & $\begin{array}{l}\mathrm{RE} \\
\text { (3) }\end{array}$ & $\begin{array}{c}\text { SGMM } \\
\text { (4) }\end{array}$ \\
\hline $\ln H_{t-1}$ & $\begin{array}{c}0.680 * * * \\
(11.871)\end{array}$ & $\begin{array}{c}0.496 * * * \\
(14.698)\end{array}$ & $\begin{array}{c}0.679 * * * \\
(11.964)\end{array}$ & $\begin{array}{r}0.503 * * * * \\
(14.797)\end{array}$ \\
\hline $\ln Y O$ & $\begin{array}{c}-0.011 \\
(0.096)\end{array}$ & $\begin{array}{c}-0.148 * * \\
(2.393)\end{array}$ & $\begin{array}{l}-0.015 \\
(0.128)\end{array}$ & $\begin{array}{c}-0.154 * * \\
(2.604)\end{array}$ \\
\hline $\ln S E C$ & $\begin{array}{c}-0.387 * * * \\
(3.453)\end{array}$ & $\begin{array}{c}-0.359 * * * \\
(5.716)\end{array}$ & $\begin{array}{c}-0.390 * * * \\
(3.520)\end{array}$ & $\begin{array}{c}-0.421 * * * \\
(6.106)\end{array}$ \\
\hline $\operatorname{lnINF}$ & $\begin{array}{c}0.039 \\
(1.067)\end{array}$ & $\begin{array}{c}0.138 * * * \\
(5.971)\end{array}$ & $\begin{array}{c}0.038 \\
(1.036)\end{array}$ & $\begin{array}{c}0.105^{* * * *} \\
(4.807)\end{array}$ \\
\hline$g$ & $\begin{array}{c}-0.641 * * * \\
(2.624)\end{array}$ & $\begin{array}{c}-0.949 * * * \\
(10.192)\end{array}$ & $\begin{array}{c}-0.631 * * \\
(2.575)\end{array}$ & $\begin{array}{r}-1.102 * * * \\
(10.420)\end{array}$ \\
\hline$S S A$ & $\begin{array}{l}0.271^{*} \\
(1.761)\end{array}$ & $\begin{array}{c}0.648 * * * \\
(7.874)\end{array}$ & $\begin{array}{l}0.277 * \\
(1.747)\end{array}$ & $\begin{array}{c}0.540 * * * \\
(5.469)\end{array}$ \\
\hline $\ln X$ & $\begin{array}{l}-0.069 \\
(0.727)\end{array}$ & $\begin{array}{c}-0.043 \\
(0.715)\end{array}$ & & \\
\hline $\ln T R A D E$ & & & $\begin{array}{l}-0.118 \\
(1.088)\end{array}$ & $\begin{array}{l}-0.034 \\
(0.510)\end{array}$ \\
\hline CONS & $\begin{array}{c}2.266^{* *} * \\
(2.294) \\
\end{array}$ & $\begin{array}{c}3.554 * * * \\
(6.068)\end{array}$ & $\begin{array}{c}2.555^{* *} \\
(2.479)\end{array}$ & $\begin{array}{c}3.726 * * * \\
(6.622)\end{array}$ \\
\hline$F$-test & 0.000 & 0.000 & 0.000 & 0.000 \\
\hline Breusch-Pagan & 0.000 & & 0.000 & \\
\hline$A R(1)$ & & 0.000 & & 0.000 \\
\hline$A R(2)$ & & 0.406 & & 0.365 \\
\hline$R 2$ & 0.77 & & 0.77 & \\
\hline$N$ & 435 & 435 & 435 & 435 \\
\hline
\end{tabular}

Notes: Period dummies included in all regressions but not reported. Sources and definitions of variables are in Appendix A2. Estimators: RE is Random Effects (Breusch-Pagan Lagrangian multiplier test for auto correlation) and SGMM is system GMM. Numbers in parentheses are $t$-ratios: *, ** and *** denote significant at $10 \%, 5 \%$ and $1 \%$ level respectively. The F-test supports the hypothesis that all coefficients are jointly significant (rejects the null that all are zero). The $J$ statistic is the Sargan/Hansen test for over-identifying restrictions. The $A R(1)$ and $A R(2)$ are tests for first and second order serial correlation of the residual in the differenced equation. For the instruments to be acceptable, the $p$-values for the $J$ statistic and $A R(2)$ test should both be greater than 0.05 , and the $p$ values for the $A R(1)$ should be less than 0.05 , i.e., there is first-order serial correlation but no secondorder serial correlation (Arrelano and Bond, 1991). The instruments appear to be acceptable. 
Figure 2.1 Marginal Effect of INT on Growth as a Function of GDP per Capita

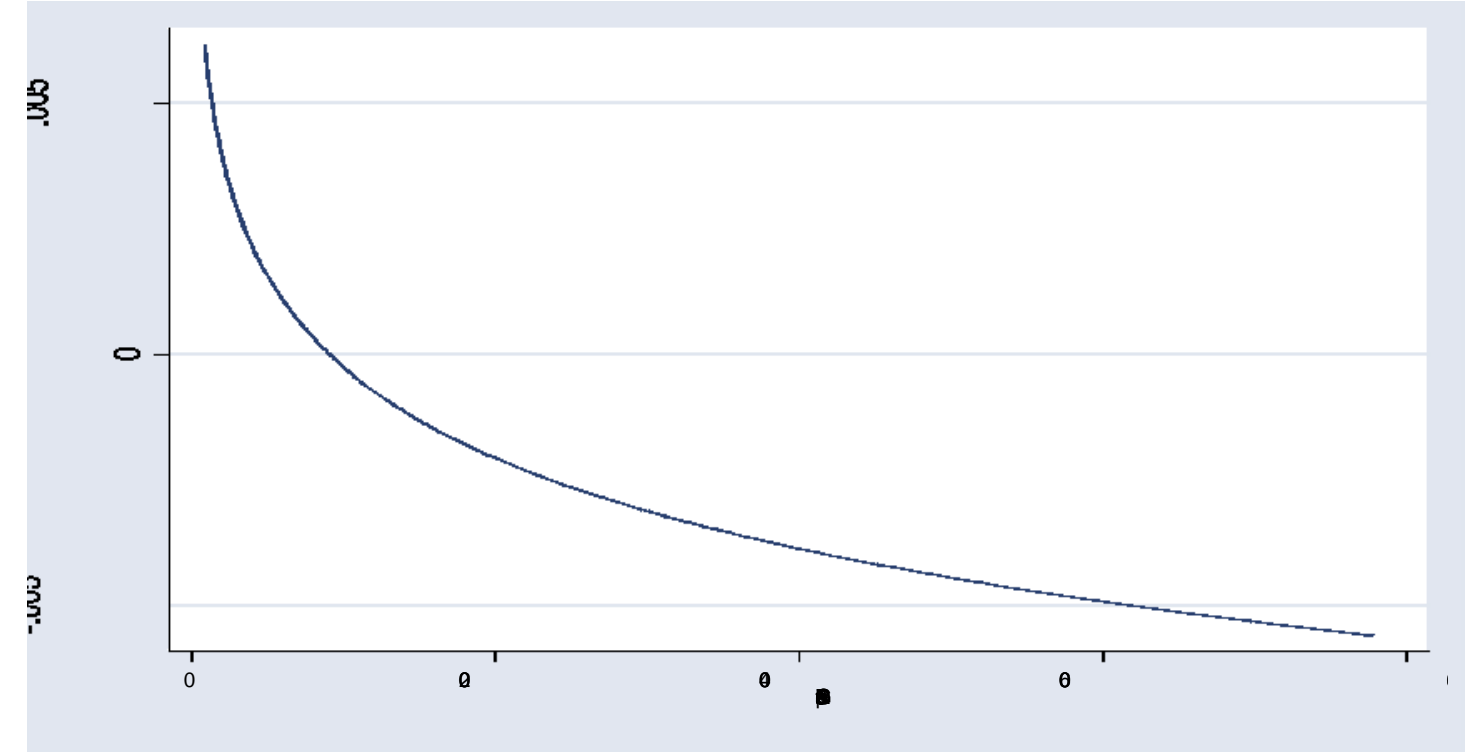

Source: Ackah and Morrissey (2007), Figure 2. 